\title{
China's Current Natural Gas Market Mechanisms and Regulatory System
}

\subsection{Current State of Natural Gas Market Mechanisms}

\subsubsection{Natural Gas Upstream Market}

In 1998, as part of the separation of government functions from enterprise management, the former China Petroleum and Natural Gas Company and the China Petrochemical Corporation were restructured according to principles of fair allocation, interaction, preservation of advantages and orderly competition, resulting in the creation of the China National Petroleum Corporation and the China Petrochemical Corporation (Sinopec). In February 2000, Star Petroleum, which had originally come under the auspices of the Ministry of Geology and Mining, was completely absorbed into the China Petrochemical Corporation. China National Petroleum Corporation, China Petrochemical Corporation and China National Offshore Oil Corporation all became independent operations, responsible for their own profitability, each an amalgamated organisation that competed both upstream and downstream. According to the regulations, these three main oil companies were allowed to apply for oil and natural gas exploration plots extending

\footnotetext{
* This chapter was overseen by Xiaoming Wang from the Development Research Center of the State Council and Mallika Ishwaran from Shell International. It was jointly completed by Yusong Deng, Jiaofeng Guo, Shouhai Chen from China University of Petroleum and Qingle Wu from Shell China. Other members of the topic group participated in discussions and revisions.
}

throughout the whole country. Even though China National Petroleum Corporation and China Petrochemical Corporation were allowed to carry out marine exploration and China National Offshore Oil Corporation could also carry out land-based exploration, other companies were still not permitted to enter to the fields of conventional gas exploration and development. When it came to non-conventional natural gas, the Coal Industry Ministry issued the Coalbed Methane Exploration and Extraction Administration Temporary Regulations in 1994, then in 2012 the Ministry of Land and Resources issued a notice encouraging shale natural gas exploration and development monitoring and regulation, which permits other market participants access to the coalbed methane and shale natural gas exploration and development field. However, the proportion of total natural gas output that this accounts for is minimal.

Currently, the majority (97\% or more) of oil and gas exploration rights and mineral rights are concentrated in the hands of the three large oil corporations. Based on Ministry of Land and Resources data, there were 1023 oil and gas exploration rights registered in China in 2012, covering 4,009,340 km², of which 942 belonged to the three main oil corporations, accounting for $3,906,848 \mathrm{~km}^{2}$, or $97.44 \%$ of the total. There were also 671 oil and gas extraction rights registered, covering a total registered area of $118,949 \mathrm{~km}^{2}$, of which 655 belonged to the three main oil corporations, covering $117,685 \mathrm{~km}^{2}$, or $98.93 \%$ of the total (see Table 11.1 and Fig. 11.1). 
Table 11.1 Oil and gas exploration rights and extraction rights registrations in 2012

\begin{tabular}{|l|l|l|l|l|}
\hline & \multicolumn{2}{l}{ Exploration rights } & \multicolumn{2}{l}{ Extraction rights } \\
\cline { 2 - 4 } & Number & Area $\left(\mathrm{km}^{2}\right)$ & Number & Area $\left(\mathrm{km}^{2}\right)$ \\
\hline China National Petroleum Corporation & 415 & $1,608,291$ & 396 & 91,578 \\
\hline China Petrochemical Corporation & 284 & 908,211 & 194 & 20,420 \\
\hline China National Offshore Oil Corporation & 243 & $1,390,346$ & 65 & 5687 \\
\hline Yanchang Oilfield & 24 & 75,958 & 5 & 444 \\
\hline China United Coalbed Methane Corporation & 24 & 18,019 & 2 & 193 \\
\hline Others & 33 & 8515 & 9 & 627 \\
\hline Total & 1023 & $4,009,340$ & 671 & 118,949
\end{tabular}

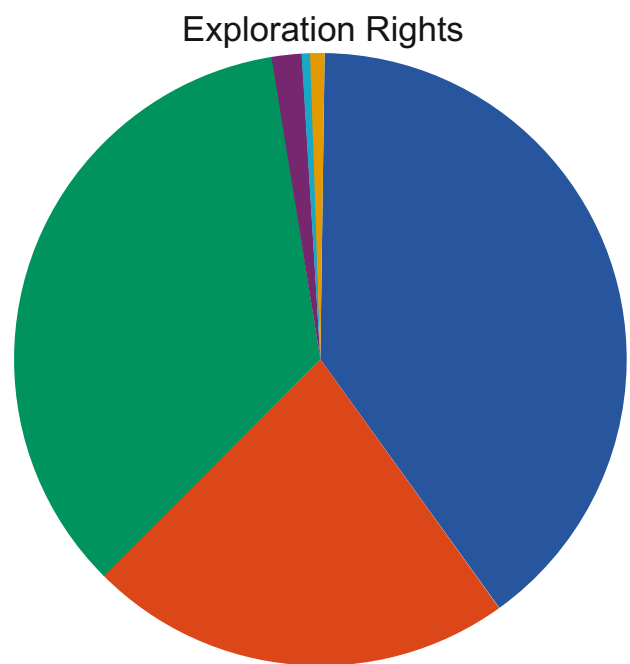

China National Petroleum Corporation

China Petrochemical Corporation

China National Offshore Oil Corporation

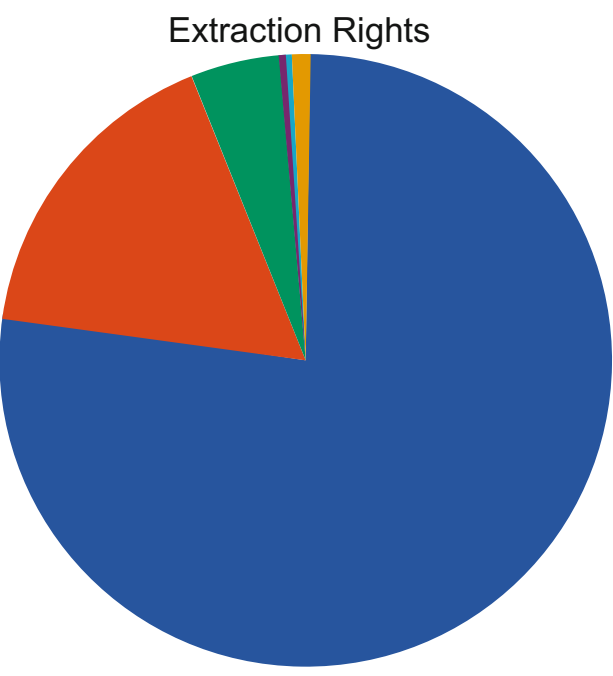

Yanchang Oilfieald

China United Coalbed Methane Corporation

Others

Fig. 11.1 Oil and gas exploration rights and mineral rights registered areas in 2012

Because the three main oil companies own the vast majority of natural gas exploration and mineral rights, in addition to owning all natural gas importing pipelines, $\mathrm{LNG}$ receiving stations and other infrastructure, the three main oil companies completely dominate natural gas supplies.

In 2014, natural gas consumption was 183 billion $\mathrm{m}^{3}$, domestic natural gas output was 125.6 billion $\mathrm{m}^{3}$, and coal-based gas output was 1 billion $\mathrm{m}^{3}$. Imported natural gas accounted for 59 billion $\mathrm{m}^{3}$, around one third of natural gas consumption. China National Petroleum
Corporation was responsible for 95.5 billion $\mathrm{m}^{3}$ of domestic gas output, 31 billion $\mathrm{m}^{3}$ of imported pipeline gas and around 5 million tonnes of LNG (approximately 6.5 billion $\mathrm{m}^{3}$ ), making up $72 \%$ of China's total natural gas consumption. China Petrochemical Corporation's domestic natural gas output was 20.2 billion $\mathrm{m}^{3}$, with 100,000 tonnes of imported LNG (130 million $\mathrm{m}^{3}$ ), accounting for $11 \%$ of China's total natural gas consumption. China National Offshore Oil Corporation's domestic natural gas output was 12.4 billion $\mathrm{m}^{3}$, with 14.11 million tonnes of 
imported LNG (18.8 billion $\mathrm{m}^{3}$ ), accounting for $17 \%$ of China's total natural gas consumption.

Overall, China National Petroleum Corporation had a three-quarter share of China's natural gas market, with China Petrochemical Corporation and China National Offshore Oil Corporation having somewhat smaller shares. In terms of regional markets, each of the three major oil companies have very high shares of the market in the regions that each supplies, in some cases reaching $100 \%$. For instance, even though Beijing has seen diversification of gas sources,with the natural gas being used including "Western gas going East", Central Asian gas, Inner Mongolian coal-based gas, imported LNG and Shaanxi-Beijing pipeline gas, this gas is provided by only one entity - China National Petroleum Corporation. However, as the Beijing Gas Group pointed out, China National
Petroleum Corporation was not actively seeking a monopoly in the Beijing market; the situation was brought about by Beijing's desire for China National Petroleum Corporation to act as the sole gas supplier, making it responsible for gas supply security. On the other hand, in south eastern coastal regions such as Guangdong and Fujian, it is China National Offshore Oil Corporation that has a relatively high market share.

\subsubsection{Natural Gas Midstream Market}

The natural gas midstream market encompasses natural gas transport and storage services, with the extent of development of the market being indicated by the scope of infrastructure present, including natural gas pipelines, LNG receiving stations and subterranean storage (see Fig. 11.2).

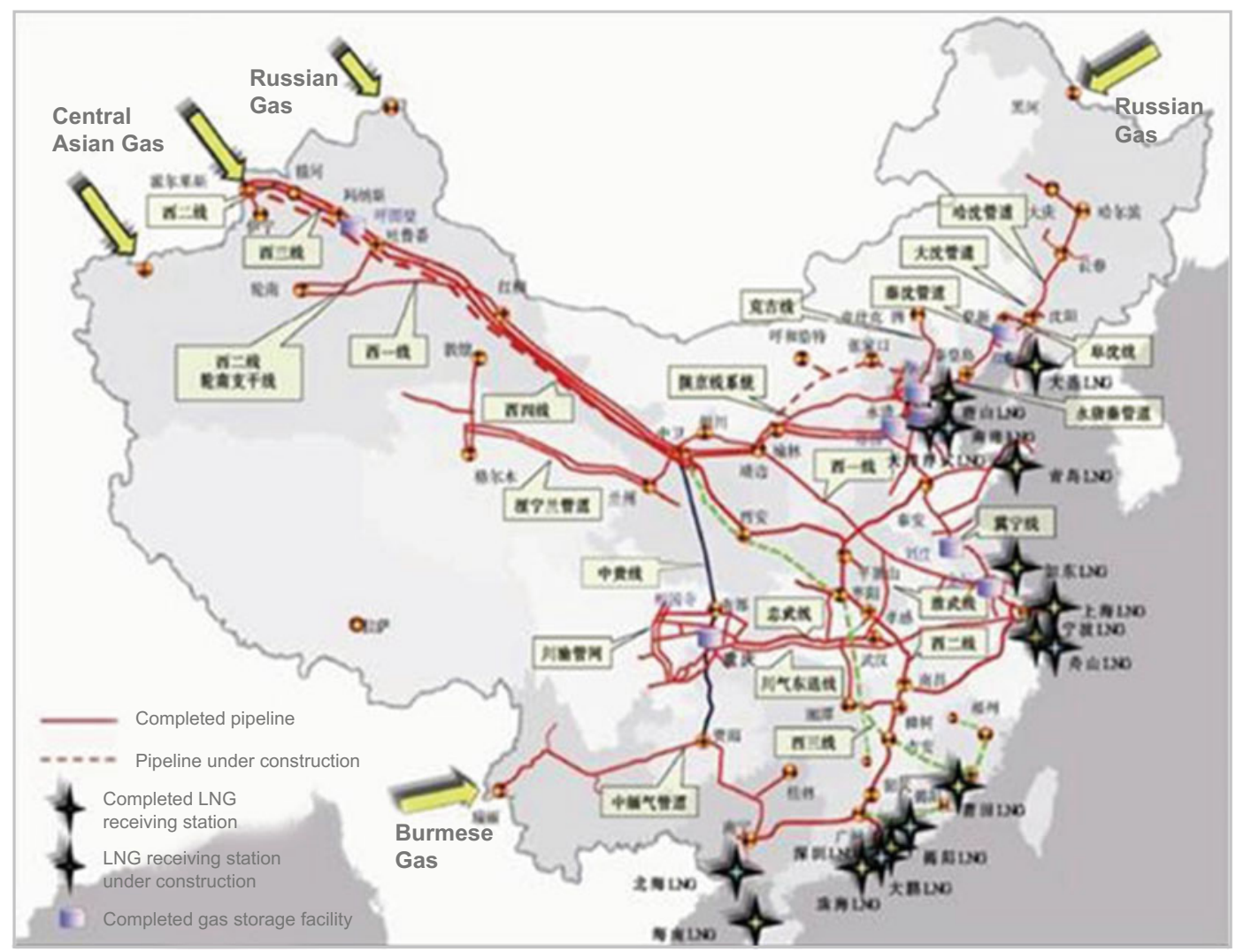

Fig. 11.2 China's natural gas infrastructure. Source China National Petroleum Corporation Economics and Technology Institute, 2014 Domestic and Overseas Oil and Gas Industry Development Report 


\section{Long-distance natural gas pipelines}

The data and statistics for the current state of construction of China's natural gas pipelines are incomplete. By the end of 2014, the main natural gas backbone pipelines and branch pipelines covered around $63,000 \mathrm{~km}$, of which around $46,000 \mathrm{~km}$ was owned by China National Petroleum Corporation, $73 \%$ of the total in China. Aside from the natural gas backbone pipelines owned by the three main oil companies, since 2003, as the natural gas market began to develop, local pipeline companies have begun to crop up, mainly owning provincial-level branch pipelines, and transporting natural gas from the backbone pipelines to municipal gate stations. In Zhejiang and Guangdong provinces there is a "complete province single network" policy, and here monopolistic provincial pipeline companies were created. In other provinces, where there were no provincial level-pipeline network companies, there are usually a number of pipeline companies; Shanxi province, for instance, has three main pipeline companies, while Henan province has almost 20. In general terms, the distances covered by local pipeline company pipelines are not great, for instance the length of pipelines completed by the Zhejiang provincial pipeline company is less than $1000 \mathrm{~km}$. Details of the main natural gas pipelines in China built after 1996 can be found in Table 11.2.

\section{LNG receiving stations}

By the end of 2014, 11 LNG receiving stations had already been completed and brought online in China, with a combined receiving capacity of 40.8 million tonnes/year (see Table 11.3). Apart from this, there are 12 more LNG gas receiving stations under construction or planned for construction, with completion due in 2017, which will further increase China's receiving capacity of 42.4 million tonnes/year, after which the combined receiving capacity will be 83.2 million tonnes/year (see Table 11.4). The completed LNG receiving stations already online are all controlled by the three main oil companies. Of the 11 completed LNG gas receiving stations, China National Offshore Oil Corporation owns 7, China National Petroleum Corporation owns 3 and China Petrochemicals Corporation owns 1. However, as the state encourages access by private enterprise to the gas and oil infrastructure industry, diversification of LNG receiving station investors is gradually taking place, and both private capital and non-oil and gas companies are competing to build LNG shore-based discharging-receiving stations. The ENN Zhoushan LNG receiving station project is already under construction, while Xinjiang Guanghui Industry Investment (Group) Company Limited, China Huadian Corporation, Hanas Group and Beijing Jingneng Power Company Limited are all actively involved in the LNG receiving station development sector.

\section{Subterranean storage facilities}

A gas shortage occurred on a national scale in the winter of 2009, exposing the severe lack of natural gas storage facilities. As a result, the natural gas administration proposed a series of measures to accelerate the construction of natural gas storage facilities. During the 12th Five-Year Plan, China National Petroleum Corporation planned to build 13 oil and gas storage banks, with a total storage capacity of $453 \times 10^{8} \mathrm{~m}^{3}$, the designed working gas capacity of which was $184 \times 10^{8} \mathrm{~m}^{3}$, while it was expected that a total working gas capacity of $170 \times 10^{8} \mathrm{~m}^{3}$ would have been created by 2015 , equivalent to $10 \%$ of China National Petroleum Corporation's sales, which should be enough to satisfy downstream peak regulation requirements. Based on the "Sichuan gas going East" and Yuji pipeline projects, China Petrochemical Corporation is conducting a comprehensive selection of gas storage sites in relation to central and eastern region oil and gas fields and the western Sichuan gas region, and, based on this, construction of key gas storage facilities is planned during the 12th Five-Year Plan at Zhongyuan Wen 96, Zhongyuan Wen 23, Jintan in Jiangsu and Huangchang in Jianghan etc. Apart from China National Petroleum Corporation and China Petrochemical Corporation using depleted oil and 


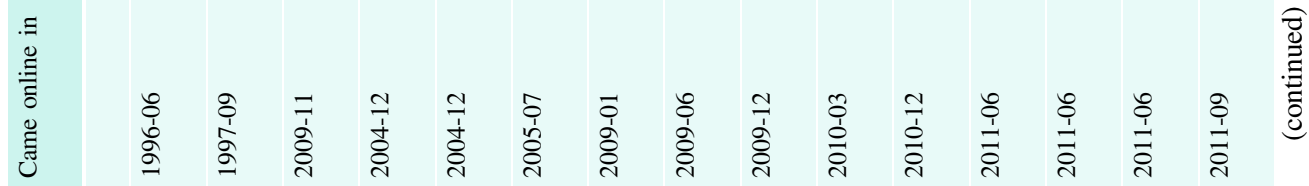

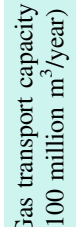

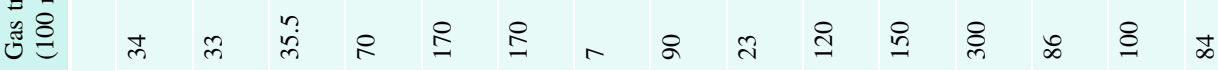

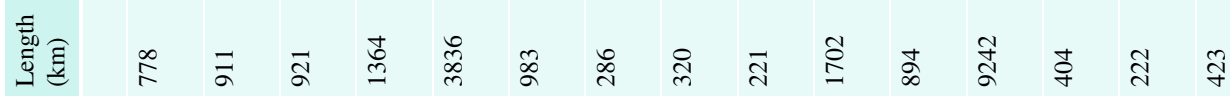

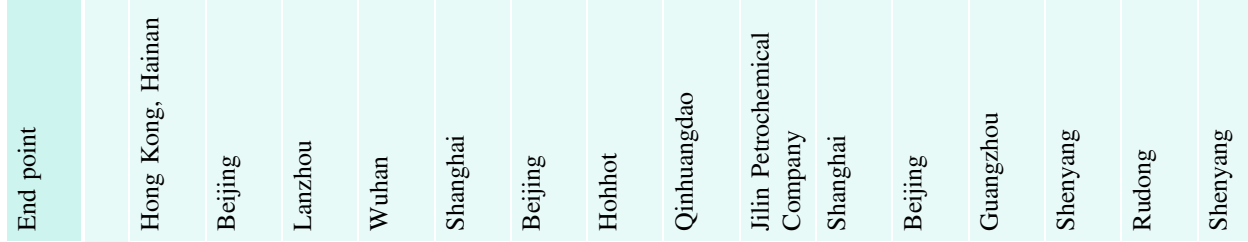

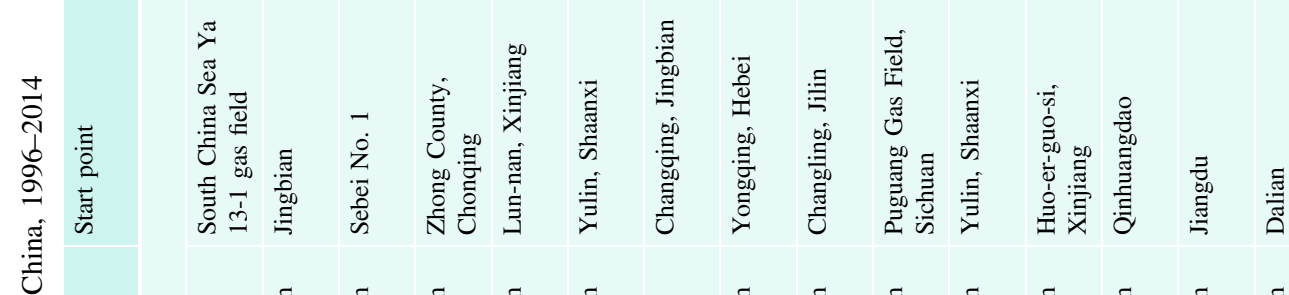

$\Xi$

吉

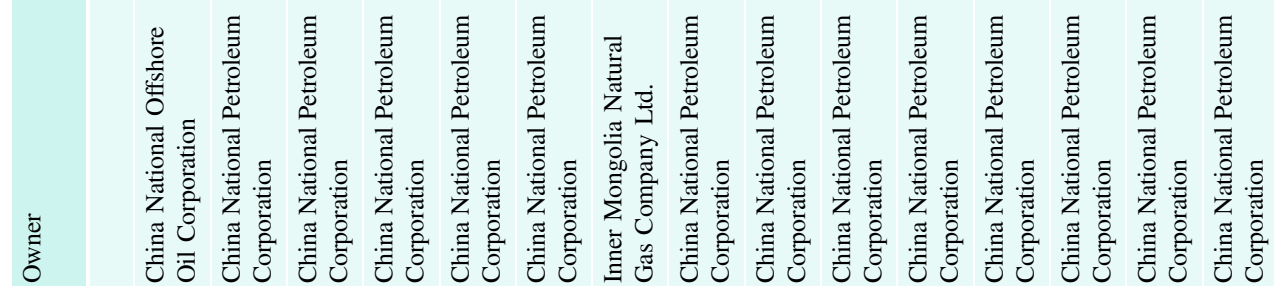

营

灵

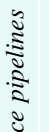

5

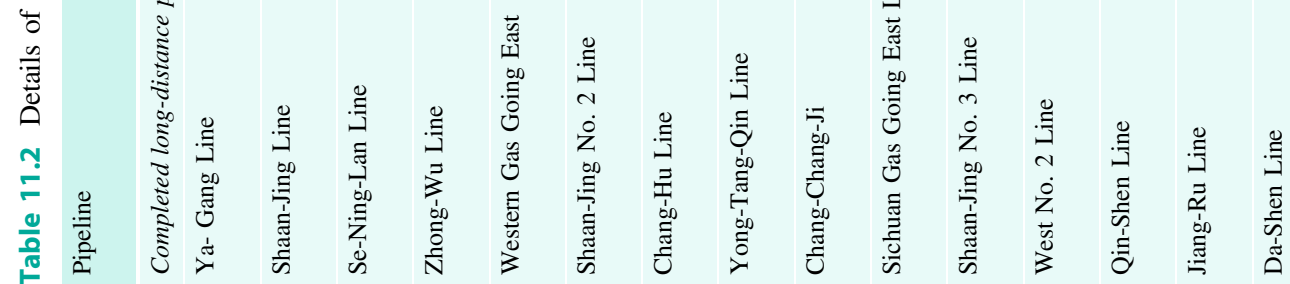




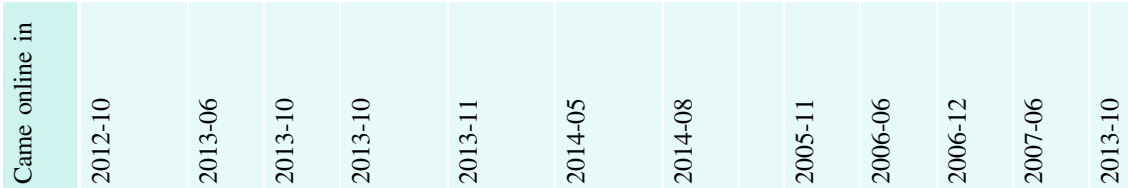

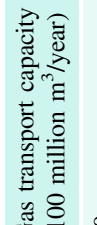

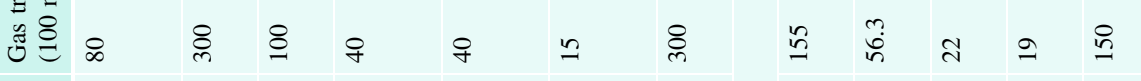

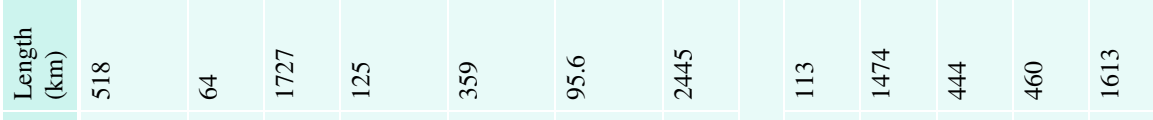

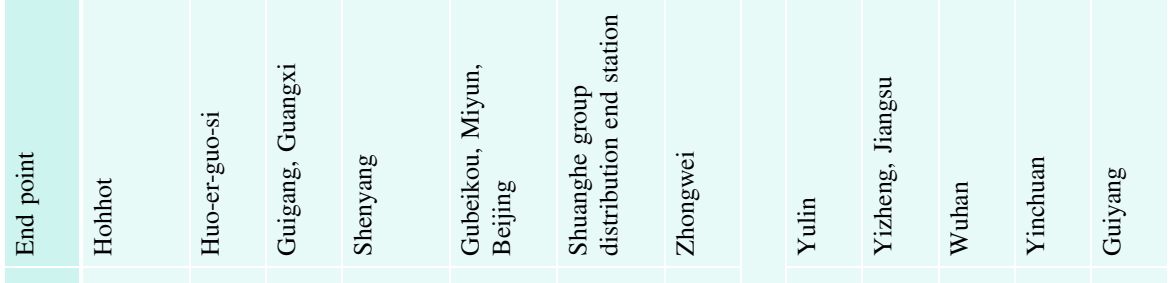

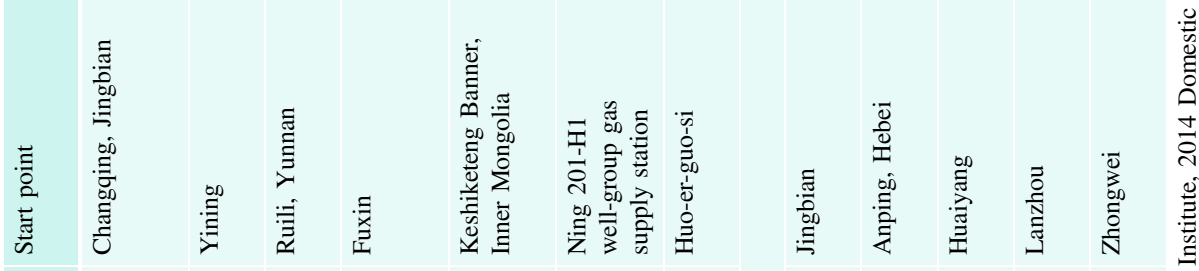

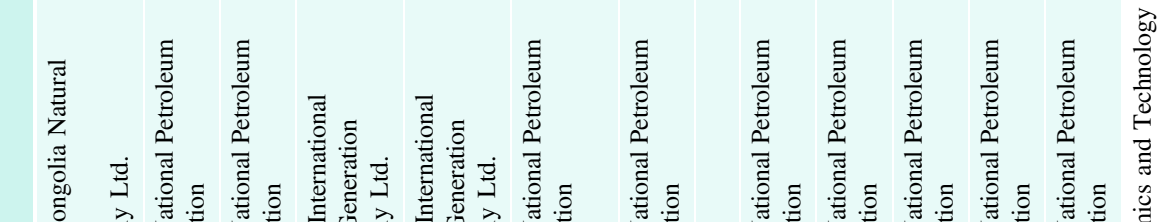

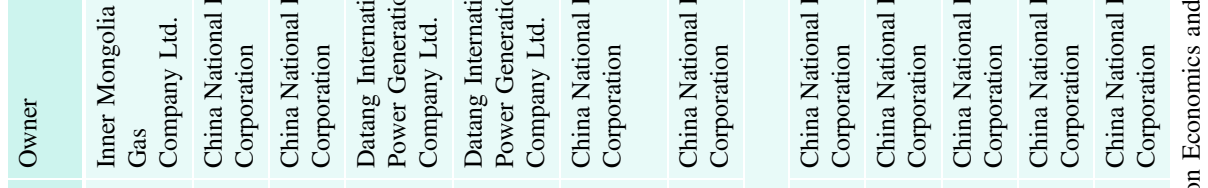

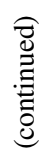

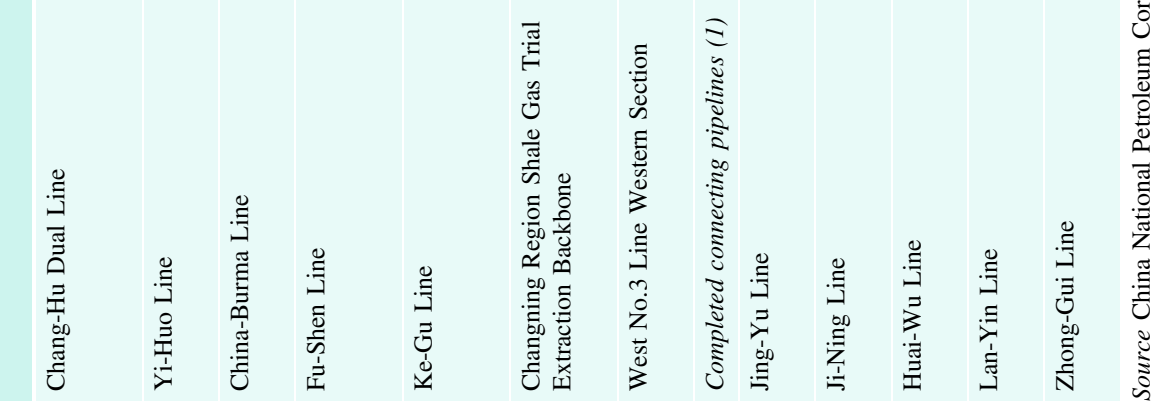




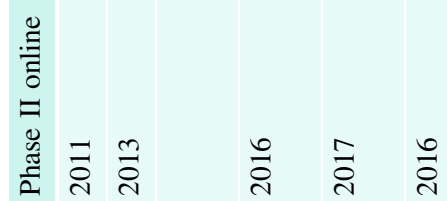

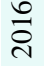

ฮัٍ

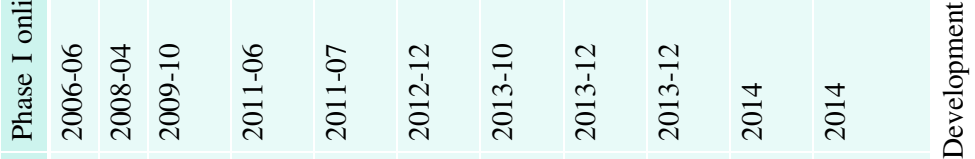

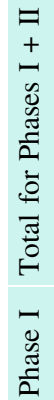

\& 8 \& 8 \& \& \&

สิ \&

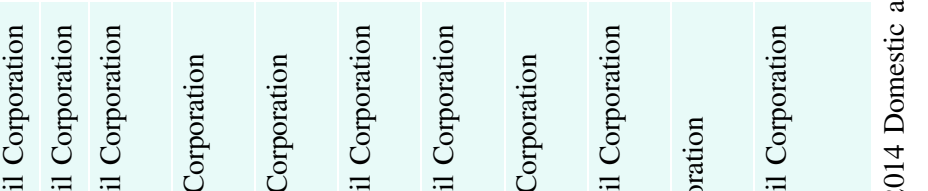

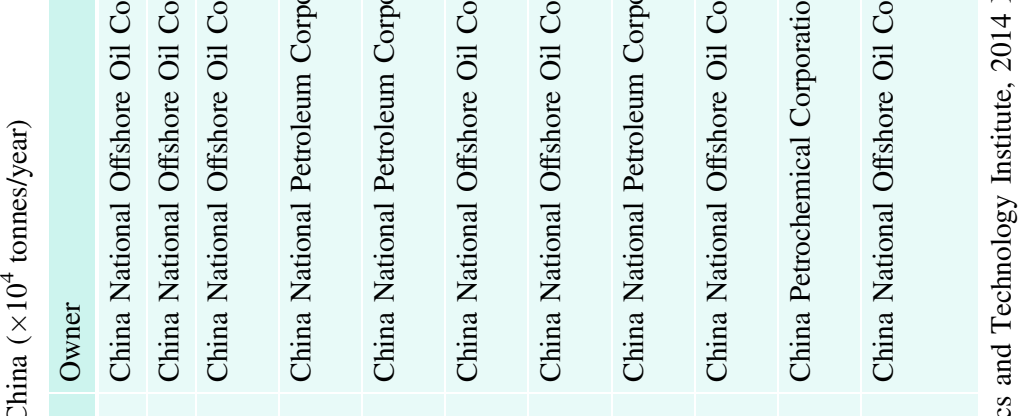

हुँ

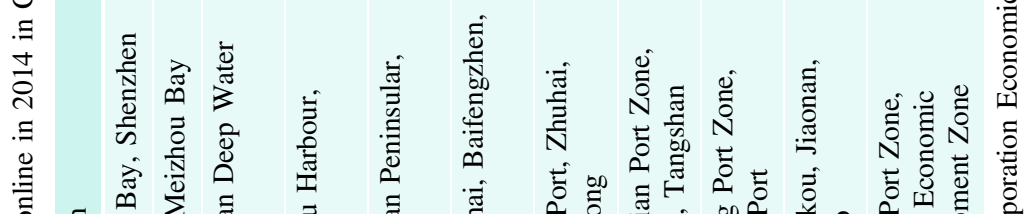

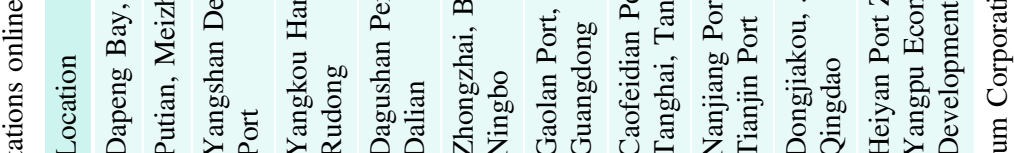

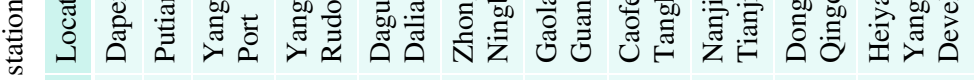

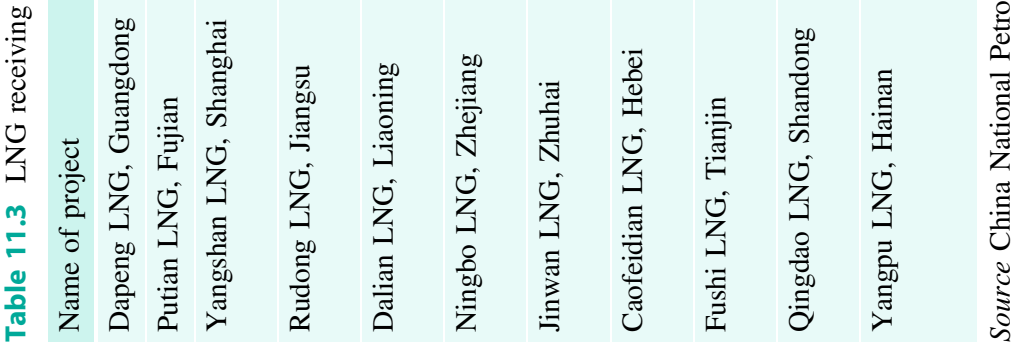



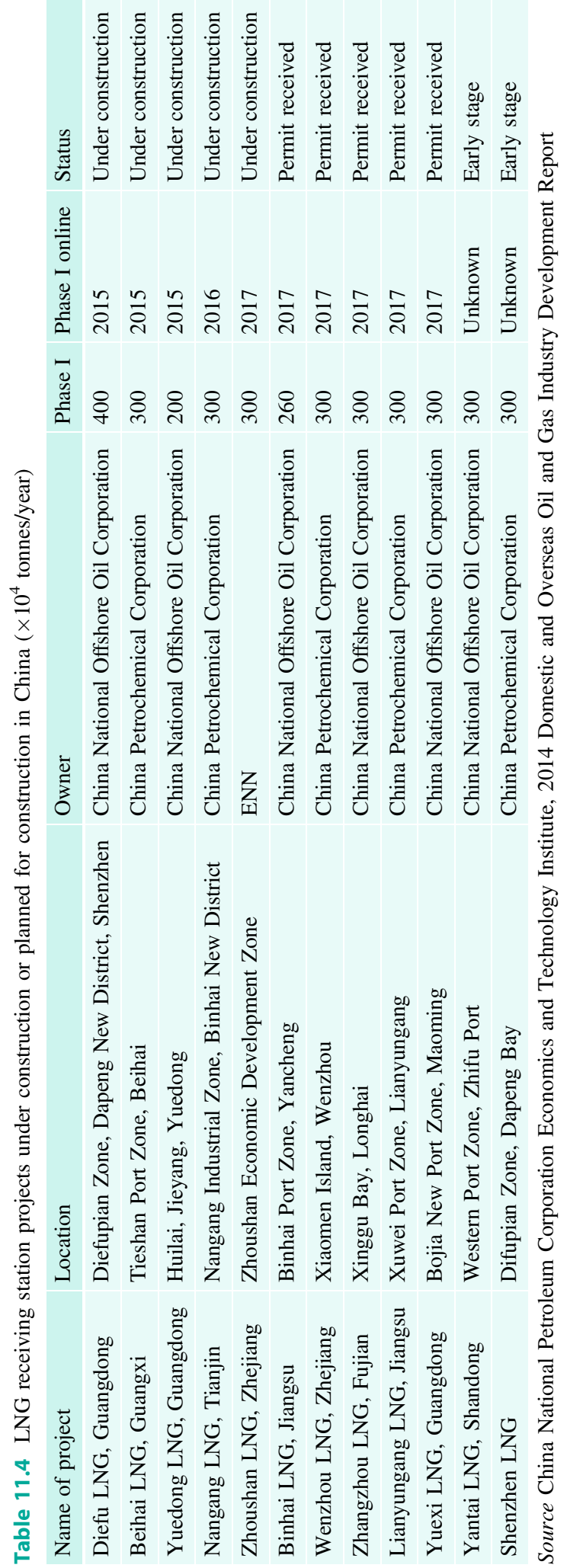
gas reserves to create subterranean storage facilities, China Petrochemical Corporation is working together with China National Salt Industry Corporation to construct gas storage facilities in subterranean salt caverns in the Jintan district of Jiangsu, while the first gas storage facility constructed with investment from a municipal gas company-Ganghua Jintan Gas Storage Facility - is already under construction. By 2013, the designed working capacity of gas storage facilities that had been completed or that were under construction had already reached 300 billion $\mathrm{m}^{3}$, but due to the need to extend subterranean storage facilities gradually, the actual completed working gas capacity is only $28.6 \times 10^{8} \mathrm{~m}^{3}$, which is only $1.7 \%$ of the current annual national gas consumption (see Table 11.5).

\subsubsection{Natural Gas Downstream Market}

The natural gas downstream market has a complex structure, and market participants are somewhat dispersed. Downstream users can be divided by gas supply method into users that are supplied directly and urban gas enterprises. Directly supplied users are those who purchase natural gas directly from upstream suppliers for the purposes of manufacturing or their own consumption, and that do not resell gas; urban gas enterprises buy gas from upstream suppliers, then resell gas to end users via their urban gas distribution networks. Direct users are generally industrial users that use large quantities of gas, but not all large industrial gas consumers are directly supplied customers. Due to the cross-subsidising that exists between residential users and commercial users in the pricing of gas supplied by urban gas enterprises, large-volume industrial users where the cost of supplying gas is relatively low are a major source of profit for urban gas enterprises. As a result, urban gas enterprises are violently opposed to upstream suppliers selling gas directly to industrial customers that fall within the geographical area to which their trading licences apply. Based on research by the China Oil Economy Institute of Technology, the quantity of gas sold by urban gas enterprises in 2013 was around 90 billion $\mathrm{m}^{3}$, which accounts for $56 \%$ of China's natural gas consumption for that year.

In December 2002, the Ministry of Construction issued Suggestions Concerning Accelerating the Rate of Marketisation of Urban Utilities, which was followed by the publication of the localised legislation and policy-related Provincial and Urban Gas Administrative Regulations in various locations. This adopted the principle that "the party investing should make decisions on policy, the party benefiting should take on risks"; this was designed to actively attract state, private and overseas investment in urban gas infrastructure and management. Currently, China's urban gas industry has begun to convert from its previously ring-fenced situation, towards one with a new "four-pronged approach" consisting of centralised corporations, local state-owned enterprises, overseas investment and private enterprises, with over 800 gas companies throughout China in addition to the formation of five major transregional gas groups, including Towngas, China Resources Gas, PetroChina Kunlun Gas Company Limited, China Gas Holdings and ENN. In addition, there are relatively large local gas groups such as the Beijing Gas Group, Shanghai Gas (Group) Company Limited and Shenzhen Gas (Table 11.6).

\subsection{Current State of China's Natural Gas Regulatory Systems}

\subsubsection{Upstream Market Administrative System}

\section{Upstream natural gas administrative policy and legislation}

When compared to the midstream and downstream sectors, market regulation and legislation in China's upstream market is relatively complete; a preliminary core Mineral and Resources Rights Law has already been drafted, 


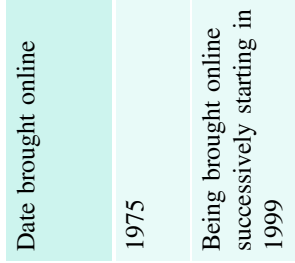

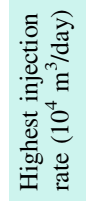

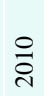

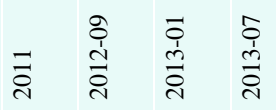

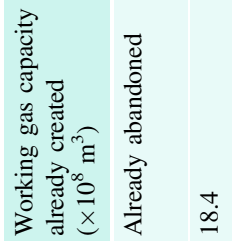

$\stackrel{+}{\stackrel{4}{*}}$

$\stackrel{\circ}{i}$

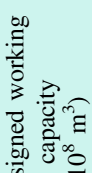

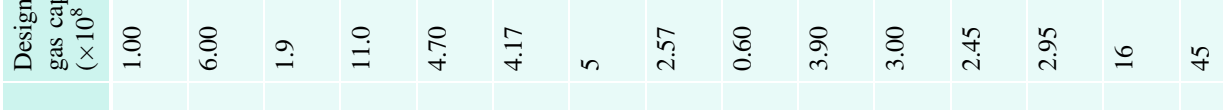

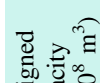

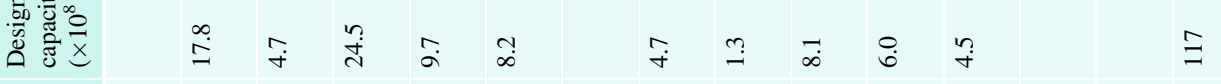

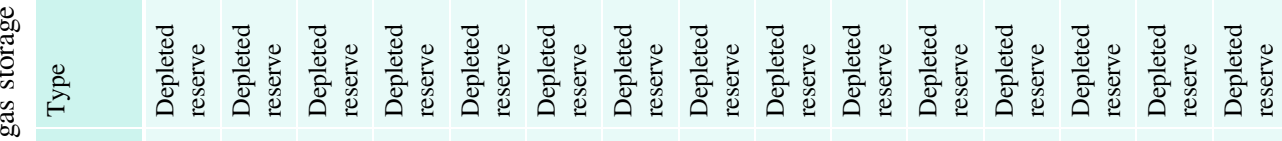

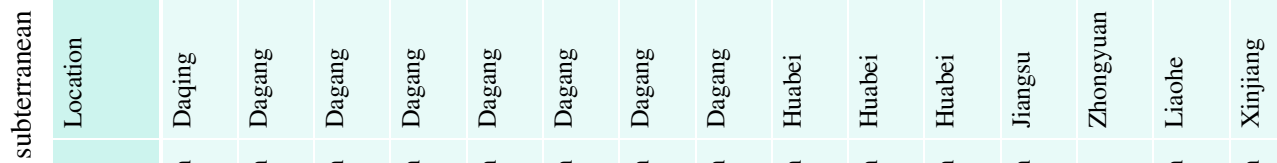

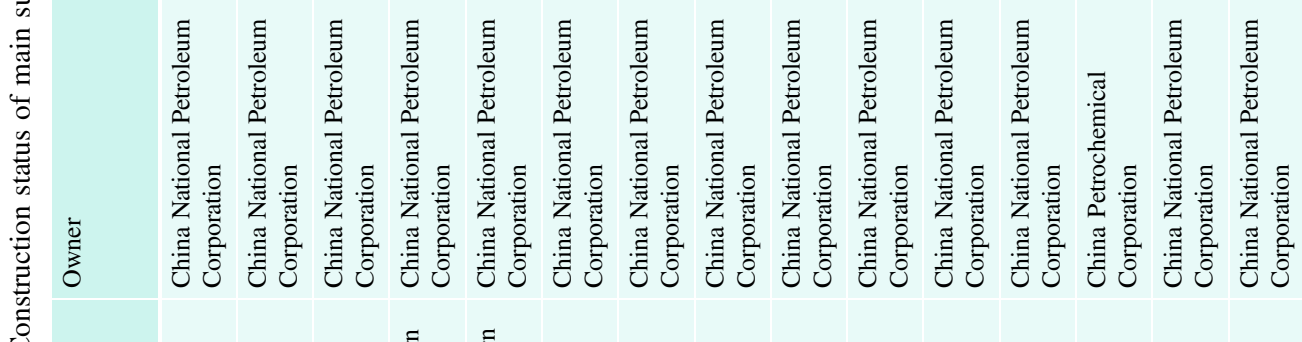

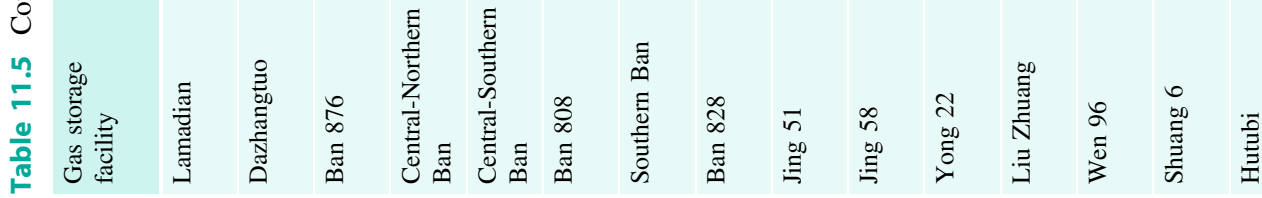




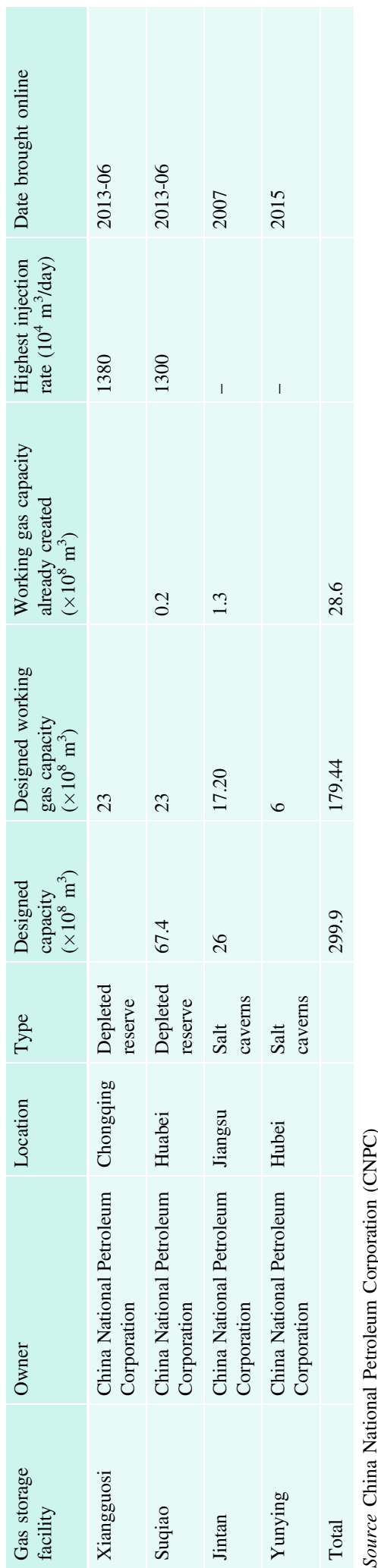

and the natural gas upstream policy and legislation is based mainly on State Council regulations and rules implemented by the industrial administration.

In terms of oil and gas mineral rights management, the main legislation applicable is the Mineral and Resources Law (1996), the Rules for Implementation of Mineral and Resources Law (1994), the Mineral and Resources Exploration Plots Registration Administrative Measures, the Mineral and Resources Extraction Registration Administrative Measures and the Exploration Rights and Mineral Rights Transfer Administrative Measures. Regarding overseas co-operation, the main legislation applicable is the Regulations for Overseas Co-operation in the Terrestrial Extraction of Oil Resources and the Regulations for Overseas Co-operation in the Marine Extraction of Oil Resources. Regarding taxation and price regulation, apart from the general legal provisions in Enterprise Income Tax Law and the VAT Temporary Regulations, the main source of legislation is the Temporary Regulations For Resources Taxation, the Administrative Regulation for the Collection of Mineral Resources Compensation and the Exploration and Mineral Rights Usage Fees and Remuneration Administrative Rules, in addition to notices issued by the National Development and Reform Commission relating to adjustment of gas prices.

The sets of mineral administrative measures that apply to coalbed methane and shale natural gas differ from those that apply to conventional natural gas, and mainly consist of policy-type documents issued by the administration, including:

- Certain Suggestions in Relation to Accelerating Coalbed Methane (Coal-mine Gas) Extraction and Usage (2006) and Suggestions in Relation to Further Accelerating Coalbed Methane (Coal-mine Gas) Extraction and Usage, issued by the General Office of the State Council;

- Temporary Administrative Regulations for the Exploration and Extraction of Coalbed Methane, issued by the Coal Industry Ministry; 
Table 11.6 Main provincial capital and urban gas enterprises in 2012

\begin{tabular}{|c|c|c|c|c|c|}
\hline No. & $\begin{array}{l}\text { Provincial } \\
\text { capital/city }\end{array}$ & Gas enterprise & No. & $\begin{array}{l}\text { Provincial } \\
\text { capital/city }\end{array}$ & Gas enterprise \\
\hline 1 & Beijing & Beijing Gas Group & 17 & Shijiazhuang & ENN \\
\hline 2 & Shanghai & $\begin{array}{l}\text { Shanghai Gas (Group) } \\
\text { Company Ltd. }\end{array}$ & 18 & Jinan & Towngas, China Resources Gas \\
\hline 3 & Tianjin & Jinran Huarun & 19 & Nanjing & $\begin{array}{l}\text { Towngas, China Resources Gas, } \\
\text { China Gas Holdings }\end{array}$ \\
\hline 4 & Chongqing & Chongqing Gas & 20 & Zhengzhou & China Resources Gas \\
\hline 5 & Guangzhou & Guangzhou Gas & 21 & Wuhan & $\begin{array}{l}\text { Towngas, China Resources Gas, } \\
\text { China Gas Holdings }\end{array}$ \\
\hline 6 & Shenyang & Shenyang Gas & 22 & Changsha & ENN \\
\hline 7 & Taiyuan & Taiyuan Coalgas & 23 & Fuzhou & China Resources Gas \\
\hline 8 & Hangzhou & Hangzhou Gas & 24 & Nanning & China Gas Holdings \\
\hline 9 & Hefei & Hefei Gas & 25 & Hohhot & China Gas Holdings \\
\hline 10 & Nanchang & Nanchang Gas & 26 & $\mathrm{Xi}-\mathrm{An}$ & Towngas \\
\hline 11 & Haikou & Minsheng Gas & 27 & Harbin & Kunlun Gas \\
\hline 12 & Guizhou & Guizhou Gas & 28 & Kunming & Kunlun Gas \\
\hline 13 & Yinchuan & Hanas & 29 & Lanzhou & Kunlun Gas \\
\hline 14 & Urumqi & Xinjiang Gas & 30 & Xining & $\begin{array}{l}\text { China City Natural Gas } \\
\text { Investment Co. Ltd. }\end{array}$ \\
\hline 15 & Changchun & Changchun Gas & 31 & Lhasa & Kunlun Energy Co. Ltd. \\
\hline 16 & Chengdu & Chengdu Gas & & & \\
\hline
\end{tabular}

- Notification Concerning Enhancing Administration of Overall Exploration and Extraction of Coal and Coalbed Methane and Notification Concerning Enhancing Supervisory and Administrative Work Relating to Shale Gas Resources Exploration and Extraction, issued by the Ministry of Land and Resources;

- Shale Gas Development Planning (20112015), Notification Concerning Various Issues in Relation to Standardisation of Approaches to the Development of the Coal Gasification Industry, issued by the National Development and Reform Commission;

- Notification in Relation to Subsidy Provision Policies Relating to Development and Usage of Shale Gas, issued by the Ministry of Finance; and

- Coalbed Methane Industry Policy, issued by the National Energy Administration.

\section{Natural gas upstream administrative bodies}

A multi-departmental shared administrative regime is employed. Apart from the Ministry of Environmental Protection and the State Administration of Work Safety, which are responsible for technical supervision of environmental protection and production safety, the main upstream administrative departments are the National Development and Reform Commission, the National Energy Administration, the Ministry of Land and Resources and the Ministry of Commerce, while the Ministry of Finance works together with the industrial administration to provide financial and taxation policy that promotes the development of the industry.

The National Development and Reform Commission (NDRC) is responsible for carrying out research into economic and social 
development policy on behalf of the State Council and is involved in maintaining a balance while carrying out macroscopic adjustments through reforms to the overall economic system. When it comes to drafting policy in relation to the natural gas industry and industry regulation, it mainly plays a role through:

- drawing up and organising strategy in relation to the national economy and social development, mid- to long-term planning and annual planning;

- prediction, forewarning and guidance information, making suggestions in terms of macroscopic policy, co-ordinating solutions for important issues affecting the progress of the economy, regulating economic activity, emergency interventions and transport-related co-ordination;

- involvement in establishing fiscal policy, currency policy and land policy, drawing up and organising the implementation of pricing strategy and the supervision and monitoring of pricing strategy implementation;

- organisation of drafting of comprehensive schemes relating to economic reforms, co-ordinating specific reforms to the economic systems, providing leadership in economic reform trials and in reform trial regional work; and

- authorisation, approval and auditing of major construction projects, projects with major foreign investment, major overseas resource development investment projects and projects requiring investment of large quantities of foreign currency.

The main duties of the National Energy Administration in terms of drawing up natural gas industrial policy and industrial supervision include:

- drafting of relevant supervisory and administrative legislation and its delivery for ratification and passing into law; drawing up and organising implementation of natural gas development strategy, planning and policy; advancing institutional reforms; drafting relevant reform schemes; co-ordination in areas of development and reform where serious issues exist;

- organising and establishing natural gas industrial policy and related standards; approvals; checking and auditing of investment in fixed-asset investment projects;

- forecasts and warnings; dissemination of data relating to natural gas; involvement in operational adjustments and emergency measures in the natural gas industry;

- drafting of national natural gas planning and policy and management of its implementation; monitoring of changes in supply and demand in both domestic and international markets; proposals concerning ordering natural gas storage equipment and suggestions concerning rotation and usage in addition to organising the implementation of such activities; approval or auditing of natural gas storage equipment and installations and monitoring and regulation of commercial natural gas storage facilities;

- supervision of fair access to natural gas pipeline network installations;

- organisation and encouragement of international co-operation relating to natural gas; co-ordinating overseas resources development and exploitation; approval or auditing of major overseas investment projects;

- involvement in establishing policy relating to resources, finance and taxation; environmental protection and responses to climate change; proposals concerning pricing adjustments and suggestions concerning total import and export quantities.

The Ministry of Land and Resources is a major upstream administration for the natural gas industry, and its main responsibilities in relation to natural gas industrial policy and industrial regulation are:

- organisation of drafting of development planning and strategy;

- drafting of legislation, establishing regulations, policy, technical procedures and standards; 
- leading local government law enforcement and investigation and handling serious contraventions;

- organisation, drafting and implementation of schemes relating to the application of mineral rights; handling rights applications; issuing exploration and development permits; auditing and authorisation of rights transfers; organisation and mediation in major rights disputes;

- standardisation and regulation of the rights market; investigation of rights holders; monitoring and supervision of extraction operations;

- regulation of the geological exploration industry and reserves of mineral resources; control over geological exploration accreditation; geological data; geological exploration results (it is legally entitled to gain from resources financially);

- authorisation of plots for foreign co-operation; supervision of foreign involvement in exploration and extraction activities.

The main role of the Ministry of Commerce in the regulation of the upstream natural gas industry is the drawing up of natural gas import policy, in the course of which they co-ordinate with other administrative departments regarding natural gas imports.

\section{Main legislative regime applying to upstream natural gas regulation}

\section{(I) Rights management}

Grade I national supervision applies to the exploration and extraction of conventional natural gas and shale natural gas, with unified planning applicable to the exploration and extraction of coalbed methane and administration at various levels, while there are differences in terms of admittance to the industry.

Applications for exploration or extraction of conventional natural gas are handled according to the Mineral and Resources Law and the mineral and resources exploration and extraction registration administrative measures, and require submission of State Council documents approving the creation of an oil company or their approval for oil or natural gas exploration or extraction, in addition to submission of evidence of the identity of the legal representative of the exploration company. Exploration permits and extraction permits can only be issued after checking, after approval by an organisation stipulated by the State Council (the National Development and Reform Commission or the National Energy Administration) and after registration with the Ministry of Land and Resources. The threshold for admission to the conventional natural gas upstream field is therefore set very high, and requires "the approval or permission of the State Council".

While Grade I national supervision also applies to shale natural gas exploration and extraction, a notice issued by the Ministry of Land and Resources about the encouragement of shale natural gas exploration and development monitoring and regulation outlines a procedure for the sale of exploration rights based mainly on tendering and other such competitive approaches, with the aim of encouraging a variety of investment entities to enter the shale natural gas exploration and extraction field. In 1994, the Coal Industry Ministry issued the Coalbed Methane Exploration and Extraction Administration Temporary Regulations, and this had no specific accreditation requirements for companies involved in the development of coalbed methane, while also promoting the use of foreign capital and the adoption of advanced foreign technology for exploration and development of coalbed methane.

\section{(II) Pricing regulation}

Due to the monopolistic characteristics of the upstream natural gas market, the upstream natural gas price has been subject to long-term government control. In June 2013, the National Development and Reform Commission issued a notice relating to the adjustment of natural gas pricing. This notice mainly dealt with converting 
natural gas price regulation from an ex-factory-based approach to a gate station approach, with the introduction of gate station pricing regulation. The original "cost plus" approach to pricing was converted to a "market netback" approach.

Gate prices are government-guided prices, with a regulated maximum price, allowing suppliers and consumers to negotiate prices within a range beneath the maximum price. Government-guided pricing only applies to state-produced terrestrial natural gas and imported pipeline gas, while the prices of shale natural gas, coalbed methane, coal-based gas and LNG have been deregulated, now being determined purely by negotiation between suppliers and consumers. The natural gas gate price is pegged against the price of alternative energy sources. The alternative energy sources adopted for this purpose are fuel oil and LPG, with weighting of 60 and $40 \%$ respectively. Distinctions are made between stock gas and incremental gas, with an approach of "old approaches apply to old gas, new approaches apply to new gas", and the incremental gas gate price is no longer based on category of use. According to a notice issued by the National Development and Reform Commission, since the April 1, 2015, the pricing of stock gas and incremental gas has been combined, with one approach to pricing being applied, and with deregulation trials adopting a directly supplied gas-user gas-use gate price.

\section{(III) Fiscal and taxation regimes}

There are four categories of fiscal policy that apply to the upstream natural gas sector:

- taxation and administrative fees in relation to the extraction of natural gas resources - these are mainly a resource tax, a mineral resource compensation fee, a mineral rights usage fee, a mineral rights cost and plot use fee etc.;

- taxation and administrative charges in relation to imported natural gas - a VAT tax rate of $13 \%$ is applied to import, while some VAT refunds are available at import in relation to "state-approved natural gas projects";
- the general tax applicable to all companies, such as company income tax and VAT etc.;

- the fiscal subsidies provided by the state in relation to the development and usage of non-conventional natural gas resources; currently the subsidy provided by central government is $0.2 \mathrm{CNY} / \mathrm{m}^{3}$ for coalbed methane and $0.4 \mathrm{CNY} / \mathrm{m}^{3}$ for shale natural gas.

\section{(IV) Overseas co-operation}

Overseas co-operation is based on the Regulations for Overseas Co-operation in the Terrestrial Extraction of Oil Resources of the People's Republic of China and the Regulations for Overseas Co-operation in the Marine Extraction of Oil Resources of the People's Republic of China. China National Petroleum Corporation and China Petrochemical Corporation are responsible for overseas terrestrial co-operation, while China National Offshore Oil Corporation is responsible for overseas maritime co-operation. Based on a notice jointly issued in December 2010 by four ministries including the Ministry of Commerce and the National Development and Reform Commission, China National Petroleum Corporation, China Petrochemical Corporation, China United Coalbed Methane Corporation Limited and Henan Coalbed Methane Development Company Limited are allowed to develop overseas co-operation in the coalbed methane sector.

\subsubsection{Midstream Market Administrative System}

\section{Midstream natural gas administrative policy and legislation}

Regulation of the midstream natural gas market is divided into economic supervision and technical supervision. Economic supervision included pricing supervision and third-party access etc.; technical supervision includes environmental supervision and safety supervision. In terms of supervisory policy and legal documents, apart from the Oil and Natural Gas Pipeline 
Protection Law issued by the National People's Congress in 2010, the main measures and regulations in force are:

- the Natural Gas Infrastructure Construction and Operation Administrative Measures, issued by the National Development and Reform Commission in February 2014;

- the Oil and Gas Pipeline Network Installation Fair Access Supervisory Measures (Trial Implementation), issued by the National Energy Administration;

- the Natural Gas Development Planning Under the 12th Five-Year Plan, issued by the National Development and Reform Commission; and

- Catalogue for the Guidance of Industries for Foreign Investment (revised 2015), issued by the Ministry of Commerce.

The Oil and Natural Gas Pipeline Protection Law's aim is to protect oil and natural gas pipelines, ensuring the security of oil and natural gas pipeline transport, and this mainly provides a legal framework for technical supervision. The Natural Gas Infrastructure Construction and Operation Administrative Measures provide fairly wide-reaching legislation regarding supervision of the midstream natural gas industry, and include natural gas infrastructure planning, construction and operation. They also include legislation covering natural gas market regulation and emergency guarantees. The Oil and Gas Pipeline Network Installation Fair Access Supervisory Measures (Trial Implementation) provide the legal framework in relation to the requirement for fair access to natural gas infrastructure, and establish the supervisory structures, supervisory duties and powers and modes of supervision that apply to ensuring fair access to natural gas infrastructure. In the Catalogue for the Guidance of Industries for Foreign Investment revised by the Ministry of Commerce in 2015, gas transportation pipelines and gas storage facilities are still listed as industries where foreign investment is encouraged. The purpose of this is to indicate openness to investment by foreign businesses, but it does not relate to construction project planning or approval, and has even less weight when it comes to the supervision of natural gas pipeline operation or storage facilities. The Natural Gas Development Planning Under the 12th Five-Year Plan proposed certain infrastructure targets and guarantees, and presented planning for a number of pipelines and gas storage facilities and other such major infrastructure construction projects, and this is the main source of guidance in terms of development of the natural gas midstream sector.

\section{Natural gas midstream administrative bodies}

Based on integrated upstream and midstream operational modes, oil companies both construct pipelines and other such infrastructure and sell and transport natural gas that they produce themselves, so there is no conflict of interests between the pipeline company and pipeline users, and economic supervisory requirements are low. As a result, there is no specialist regulatory body. From the point of view of natural gas industry regulation, China adopts an approach whereby governing and regulation are combined, but there are a number of different bodies involved. The midstream natural gas administration includes the National Development and Reform Commission, the National Energy Administration and natural gas administration departments of People's Governments at the province, autonomous region and directly governed city levels, and these also take responsibility for economic supervision of the midstream natural gas industry. Technical supervision is carried out by geological, quality monitoring, environmental protection and production safety departments of local People's Governments.

The National Development and Reform Commission and the National Energy Administration are responsible for planning of national natural gas infrastructure construction. The natural gas administration departments of province, autonomous region and directly governed city People's Governments, on the other hand, act in line with national planning in drawing up natural 
gas infrastructure development plans for their administrative districts, submitting reports of such activities to both the National Development and Reform Commission and the National Energy Administration. Planning departments are responsible for approval, auditing and recording of construction of natural gas infrastructure. Authorisation documents relating to natural gas infrastructure projects authorised or approved by province, autonomous region and directly governed city People's Governments are submitted to the National Development and Reform Commission. Where a natural monopoly exists, natural gas infrastructure services are subject to government pricing control, with the National Development and Reform Commission and pricing departments at province, city and autonomous region level being responsible for determining the natural gas infrastructure service prices. The National Energy Administration and bodies under its auspices are responsible for supervisory work where it comes to fair access to natural gas pipeline networks.

\section{Midstream market supervision}

Midstream market supervision mainly involves establishing planning, project approval (authorisation), pricing control and enforcing the law etc.

The Natural Gas Development Planning Under the 12th Five-Year Plan issued in 2012 was the first-ever natural gas-specific planning in China. The main focus was to develop the natural gas industry by proposing development targets, policy assurance measures and major construction projects, and this provided guidance to lead the way for business investors. Based on the regulations, natural gas infrastructure construction projects required authorisation, approval or filing by industrial administration departments; if a project had not been authorised, approved or filed, then that project could not commence construction. Pricing for services in relation to naturally monopolistic natural gas infrastructure such as pipelines is controlled by the government, with service charges being collected based on prices set by government pricing departments.
Because "administrative measures" issued by the National Development and Reform Commission and the National Energy Administration fall into the category of ministerial regulations, they do not carry weight in terms of establishing administrative penalties. The punitive measures available to supervisory departments are therefore limited; apart from warnings and correction orders, they mainly rely on pricing law, anti-monopoly law and contract law to enforce the legal responsibilities of the relevant enterprises.

\section{Midstream market regulation}

In countries where reform of the natural gas market is advanced, such as the UK and the US, natural gas industry regulation mainly involves midstream regulation. This results in "supervision of the middle with freedom at both ends", thus creating an " $X+1+X$ " market structure. In " $X+1+X$ ", the first $X$ is the upstream supplier, the second $\mathrm{X}$ is the downstream user, and the 1 in the middle is the midstream pipeline network. "Supervision of the middle" refers to implementing strict supervision of natural pipeline network monopolies, enforcing a regime of third-party access and exerting control over pricing. Due to the long-term application of monopolistic operation to the upstream sector in China's natural gas industry and the unified mode of operation encountered in the midstream and upstream sector, a third-party access regime has never been established, and the majority of regulation relating to pipeline transportation prices stems from natural gas pricing requirements.

The first time that "fair access" was mentioned was in the Natural Gas Infrastructure Construction and Operation Administrative Measures, issued by the National Development and Reform Commission in February 2014, and the Oil and Gas Pipeline Network Installation Fair Access Supervisory Measures (Trial Implementation), issued by the National Energy Administration. The Natural Gas Infrastructure Construction and Operation Administrative Measures stipulate that natural gas infrastructure operators: 
- should publicise information, including conditions of service provision, the procedures for obtaining such services and excess service capacity, and provide fair and just pipeline transport, gas storage, gasification, liquefaction and compression services to all users;

- may not use infrastructure in a manner that discriminates against other natural gas enterprises;

- where there is sufficient capacity, may not refuse to provide services to users who satisfy the necessary conditions; and

- may not make unreasonable demands.

The Oil and Gas Pipeline Network Installation Fair Access Supervisory Measures (Trial Implementation) defines the regulations relating to the conditions and procedures for handling user access applications and specific regulatory methods in more detail.

\subsubsection{Downstream Market Administrative System}

The downstream natural gas administrative system includes supervisory bodies, policies and legislation, in addition to main supervisory regimes.

\section{Supervisory bodies}

There are users in the downstream natural gas industry sector who are directly supplied by the upstream sector. There are also residential and commercial users, small industrial users, distributed power generation users and transport users who are supplied with gas via urban distribution networks. Where directly supplied users with larger gas consumption are concerned, such as gas for power generation, industrial fuels, gas for use in chemicals etc., the focus of government economic supervision is mainly the price of gas supplied and the fields in which gas is used. Currently, the National Development and Reform Commission is responsible for issuing natural gas pricing and natural gas use policy.
From the point of view of users supplied via the urban distribution networks, the main focus of government economic supervision is industry planning, control over admission to the gas industry, project allocation, price regulation, emergency assurance and so on, and the main object of such supervision is the gas companies. According to the regulations laid out in the urban gas administrative regulations, the State Council is responsible for the creation of administrative departments with responsibility for natural gas supervisory work at the national level. According to the relevant laws and regulations, People's Government gas administration departments at town level and above are responsible for determining and adjusting pipeline gas sales pricing, safety monitoring, quality inspections and provision of firefighting services, while other departments are responsible for specialist technical supervision.

\section{Policy and law}

Supervision of the downstream natural gas industry includes technical supervision and economic supervision. Technical supervision relates to supervision of product quality, of standards applied in engineering and construction and of safety in production. Economic supervision relates to supervision of admittance to the industry, of natural gas sales prices, of gas use sectors and of gas supply responsibilities. Generally, within policy or legislative documents, there may be both technical supervisory content and economic supervisory regulations. The Urban Gas Supervisory Regulations issued in 2010 are one such example of generalised administrative regulations, including both urban gas development planning and emergency assurances, and covering areas of economic supervision such as urban gas business and services, in addition to technical supervisory regulations relating to gas use, protection of gas installations, gas safety and prevention of accidents and their handling.

Certain specialist policies and legislation do exist in relation to downstream natural gas 
industry supervision. These mainly consist of natural gas usage policy and pricing regulation documents issued by the National Development and Reform Commission, and national urban gas development planning issued by the Ministry of Housing and Urban Construction, as well as urban gas supervisory regulations issued in 2010 by the State Council. Apart from this, contract law, emergency response law, product quality law, pricing law, fire prevention law, production safety law, metering law, special equipment safety inspection law, safe administration of dangerous chemicals regulations, housing construction and municipal infrastructure project completion and inspection filing administrative regulations and other such general law and regulations are also dealt with by downstream natural gas industry supervision.

\section{Special business licence regime}

In order to implement the reform demands expressed at the Sixteenth National Congress concerning "increasing reform to monopolistic industries, actively introducing competition mechanisms", in December 2002 the former Ministry of Construction issued Suggestions Concerning Accelerating the Rate of Marketisation of Urban Utilities, which suggested encouraging the involvement of social and overseas capital in the form of sole ownership, joint ventures and co-operation in the construction of municipal public utility infrastructure, to construct commercially operated municipal public utility facilities for water supply, gas supply, heating supply, waste water processing and waste treatment; tendering would allow selection of investment entities and would allow trans-regional and cross-industry involvement in the operation of municipal utilities enterprises, with special permits to be awarded by the government for such business operations. In 2004, regulations in the Municipal Public Utilities Business Licence Administrative Measures stated clearly that permitted municipal public utility operators are investors or operators of municipal public utilities that have been selected by the government on the basis of relevant laws, statutes and regulations according to a market competition regime, and clearly outlines a regime whereby they may trade in certain public utility products or provide such type of services within a certain range and for a certain period of time. The special permits regime gives priority to appointments relating to specific business schemes, via a tendering process that allows selection of the best company, to which a special operators permit is awarded.

According to the Municipal Public Utilities Business Licence Administrative Measures, entities taking part in tendering for special business licences should:

- be a legally registered business entity;

- have corresponding registered capital, installations and equipment;

- have a good credit rating, be in good financial condition and be capable of servicing any outstanding debt;

- have experience in such operations and have a good business record;

- have sufficient key technical, financial and operational staff;

- present a realistic and feasible business plan;

- comply with any other conditions according to local laws and regulations.

After authorisation by People's Governments at the directly governed city, city and town level, government departments could then sign a business licence agreement with the successful bidder (the company that was awarded the special operators permit), the content of which included: the specifics of the permitted business operation, its geographical extent, its scope and duration; product and service standards; methods and standards for determining prices and fees and procedures for their adjustment; ownership and disposal of facilities; facility maintenance, update and conversion; safety management; performance guarantees; termination or alteration of terms of the permitted business operations; 
liability for breach and methods of resolving disputes etc. Special business licence durations depended upon such factors as the type of industry, the scale of the operation and type of business and did not exceed 30 years.

\section{Gas business licences}

In July 2004, after the Administrative Licensing Law was issued, the original urban gas company accreditation administrative regime was rescinded, and the majority of provinces and directly governed cities drew up or revised local regulations and statutes to create a gas business licence regime. Clause 15 of the Urban Gas Supervisory Regulations of 2010 states that the state has adopted a business licence regime for gas businesses, and that companies involved in conducting gas business activities should satisfy the following conditions:

- they should satisfy the requirements of gas development planning;

- they should possess fuel gas sources and gas facilities that satisfy the national standards;

- they should have a fixed business address, a complete safety management regime and a complete business plan;

- the main person responsible for the business, the production safety manager and operational, maintenance and emergency repair staff should all have undergone professional training and have been found satisfactory;

- other conditions applicable according to legal and statutory regulations.

If these conditions are met, then the gas departments (at town level) and People's Governments (for larger areas) may issue gas business licences. It is clear from these regulations that the standard for the award of a gas business licence is "satisfactory" (satisfies the conditions), and as such, those that satisfy such conditions should all be awarded business licences.

\subsection{Challenges Faced by the Current System}

\subsubsection{Over-Centralisation of Mineral Rights and Lack of Exploration}

There are already oil and gas exploration rights registered in relation to 4 million $\mathrm{km}^{2}$ across China as a whole. Of these, 3.9 million $\mathrm{km}$ (over 97\%) belong to the three main oil companies, China National Petroleum Corporation, China Petrochemical Corporation and China National Offshore Oil Corporation. Oil and gas extraction rights already registered cover an area of 118,000 and $117,000 \mathrm{~km}^{2}(99 \%)$ of these belong to the three main oil companies. The monopolistic position of the three main oil companies in terms of upstream exploration is hardly the result of free competition, but is rather due to legal restrictions and administrative monopolies. Based on the Mineral and Resources Law, the regulations governing mineral and resources exploration and the administrative measures governing the registration of extraction plots, applications to carry out exploration and extraction of oil and natural gas must be approved or agreed to by the State Council, but in actual practice only a very small number of companies ever receive such authorisation or permission.

Even though the exploration and extraction of shale natural gas, coalbed methane and other non-conventional types of natural gas is now open to other types of company, the number of plots actually accessible is limited, and the three main oil companies continue to dominate non-conventional natural gas extraction. The reason for this is that, in the majority of circumstances, non-conventional natural gas (mainly shale natural gas) plots coincide to a large degree with conventional natural gas plots. Apart from the legal restrictions, there are issues whereby it has not been possible to implement total third-party access to infrastructure, resulting in technical barriers arising in terms of extraction, 
and presenting difficulties for other companies trying to enter the upstream sector of the natural gas industry.

Due to the legal restrictions and the administrative protection of these monopolies, the three main oil companies virtually dominate all available oil and gas exploration plots. However, there is still a major lack of exploration. According to the Mineral and Resources Exploration Plots Registration Administrative Measures, owners of exploration rights should invest not less than $2000 \mathrm{CNY} / \mathrm{km}^{2}$ in exploration within one year of the date on which the exploration permit was issued, rising to $5000 \mathrm{CNY} / \mathrm{km}^{2}$ in the second year and $10,000 \mathrm{CNY} / \mathrm{km}^{2}$ in the third. The Mineral and Resources Exploration Plots Registration Administrative Measures were issued in 1998 and were applied to all types of minerals, based on today's prices, and the level of investment that would be required for exploration for oil or gas (an annual exploration investment of $10,000 \mathrm{CNY} / \mathrm{km}^{2}$ ) is unquestionably far too low.

In November 2014, the Ministry of Land and Resources subjected China Petrochemical Corporation and Henan Coalbed Methane Development Company Limited to fines of $\mathrm{CNY}$ 7,978,800 and CNY 6,035,500 respectively, and ratified reduction of the extent of their exploration plots. The reason for this was that these two companies had not been able to carry out exploration to the extent of their undertakings. Even though China Petrochemical Corporation and Henan Coalbed Methane Development Company Limited had only completed 73 and $51 \%$ of their undertakings in relation to exploration, their actual investment had already reached a level equivalent to 11.6 times and 3.6 times the level of investment required by law, respectively. According to China Petrochemical Corporation's annual accounts, China Petrochemical Corporation's investment in exploration in 2013 was only CNY 25.3 billion, which would be the equivalent of exploration of $1,600,000 \mathrm{~km}^{2}$ of registered exploration rights, and based on this their average exploration expenditure was only $15,800 \mathrm{CNY} / \mathrm{km}^{2}$. In actual fact, that CNY 25.3 billion also included the cost of overseas exploration, therefore it should not all be allocated to areas of domestic exploration.

\subsubsection{Bundling of Infrastructure, Low Utilisation and Blocking Access to Upstream Markets}

From the point of view of developing the natural gas market, building pipeline infrastructure is enormously important. Construction of natural gas pipelines and other infrastructure requires massive investment, with investment in backbone pipelines often reaching between tens and hundreds of billions of CNY, and branch pipelines costing between billions and tens of billions. The structure of every country's natural gas market is different, so variations in gas industry development and the types of infrastructure investment entities will naturally differ. In the early development stages of the US natural gas market, the upstream was very dispersed, and it was therefore often the downstream urban gas companies that were responsible for extending pipelines to oil and gas fields, where they bought gas for transport to, and sale in, downstream markets. In China, the development of the natural gas industry has followed the exactly opposite path; there is a relatively high level of monopoly upstream, while downstream it is relatively dispersed, and generally it is the upstream companies that are responsible for construction of pipelines and transport of natural gas for sale in downstream markets. In both cases, the approach adopted at the early stage involved bundling of pipeline transport and natural gas sales, with pipeline transport enterprises using their own pipelines to transport and sell natural gas.

Natural gas pipeline natural monopolies and bundling of business affects fair competition between upstream enterprises. In the United States in 1938, the Natural Gas Act introduced control over wellhead prices that continued for 40 years. The initial aim was to prevent pipeline transport companies from treating dispersed upstream producers unfairly. As described elsewhere, inappropriate wellhead price control 
eventually restricted the development of the natural gas industry in the United States, resulting in the severe gas shortages that occurred in the 1970s. In 1985 and 1992, the Federal Energy Regulatory Commission (FERC) issued Order 436 and Order 636, which introduced third-party access (TPA) and division of business, providing the basic conditions for the formation of a highly effective competitive natural gas market, while also acting as a stimulus for the shale natural gas revolution that has occurred in the US.

In February 2014, the Natural Gas Infrastructure Construction and Operation Administrative Measures and the Oil and Gas Pipeline Network Installation Fair Access Supervisory Measures (Trial Implementation), issued by the National Development and Reform Commission and the National Energy Administration respectively, stated that natural gas infrastructure operators should provide fair and open access to their services. However, without strict supervision, the "fair access" required by the Oil and Gas Pipeline Network Installation Fair Access Supervisory Measures (Trial Implementation) is actually "negotiated access" rather than fair third-party access. On top of this, neither of these two measures actually require the division of pipeline services from natural gas sales business. Although there is currently no actual evidence that bundled natural gas pipeline business operations act as an obstruction to entry to the upstream fields of exploration and extraction, in the second half of 2014, against the backdrop of a major drop in international oil prices, bundled operation of LNG receiving stations and long-term agreements in relation to gas prices were definitely responsible for obstructing the import of low-priced LNG from the international markets.

\subsubsection{Irrational Pricing Mechanisms, Which Dampen Incentive to Build Gas Storage}

The pricing reforms in 2013 were a major step forward in terms of liberalisation of the mechanisms that go to shape natural gas prices. However, prices are still not determined by the market; the transition from "cost plus" to "market netback" has only altered the method applied to pricing, rather than changing the actual price-determining mechanism. There are a lot of artificial factors at play in the choice of alternative energy source type, and these may not actually reflect the market value of natural gas. Taking the United States as an example, between 2000 and 2008, the price of fuel oil continued to rise while the price of natural gas virtually stayed the same. In 2010, with the arrival of the shale natural gas revolution, prices of fuel oil and natural gas began to deviate, with fuel oil increasing in price by one third, while the natural gas price dropped by two thirds. Against the backdrop of the widespread adoption of energy saving, emissions reduction and pollution control, the demand for coal dropped, as did the price, while the demand for gas continued to grow, as did the price, their prices changing in opposite directions. Therefore, adopting the price of coal to determine the price of natural gas makes no sense. Even if one tries adopting fuel oil and LPG as references, the changes in their prices still don't fully reflect the changes in supply and demand in the natural gas market, due to the differences in their uses and the difficulties in fuel conversion, and this may result in investors and natural gas users being exposed to erroneous market signals.

According to the pricing reforms of 2013, the natural gas gate station price was adjusted once a year based on the alternative energy source prices against which it is pegged, gradually transitioning to six-monthly and then quarterly adjustment. Regardless of whether adjustments take place once a year or at six-monthly or quarterly intervals, this year's natural gas price is still based on last year's alternative energy source prices. By making an adjustment once each quarter, the winter natural gas price is based on the autumn alternative energy source price. Warmer temperatures in autumn result in there being less need for heating and a relatively low demand for energy sources. Adopting the autumn alternative energy source price when deciding the price of 
gas for the peak gas use winter season is counterintuitive. So with a government-determined price based on the "market netback" approach, adjusted once a year or once each quarter, there is limited scope for adjustment and no capacity to reflect changes in supply and demand in the natural gas market up to the actual moment when the decision is made. Such an approach is not an attractive proposition to natural gas companies, given the massive levels of investment required to construct natural gas storage facilities. Unsurprisingly, gas storage facility working gas capacity in the US is between 18 and $20 \%$ of annual consumption, while in China it is only $2-3 \%$.

\subsubsection{Downstream Pipeline Operator Regional Monopolies and Cross-Subsidising Between Different Users}

Although the reform of public utilities that started in 2002 resulted in competition in terms of market admission, it also had the effect of reinforcing monopolistic business operations. Companies that were awarded special business licences were allowed to carry out bundling of natural gas sales and network distribution over a period of time and within a certain range, thus excluding the possibility of competition occurring with other companies. Not only did these other companies encounter problems supplying gas to end users via urban gas networks, such activities as construction of pipelines to supply end users directly were also seen as an infringement of the special business licences awarded to urban gas companies. In addition to various urban gas companies being awarded special permits for supply of gas on the urban level via the tendering process, some provinces also set up provincial pipeline network companies, which then enjoyed provincial monopolies in purchasing and sales of natural gas. As a result, other companies were prevented from investing in and constructing natural gas pipelines in those provinces.
- Due to the monopolistic nature of urban natural gas networks and the bundling of sales and distribution, government-set pricing is generally applied to natural gas sold by urban gas companies. There are issues where pricing of urban gas is concerned.

- The pricing mechanisms are inflexible - since there is a mismatch between upstream and downstream pricing, the downstream price cannot immediately reflect changes in upstream gas source prices.

- It is difficult to monitor gas supply costs, and the pricing methods are somewhat opaque, so urban gas pricing departments find it hard to gain a clear understanding of the actual cost of gas supplied to urban gas companies, and there is no unified pricing method.

There is a mismatch between the natural gas sales price and the cost of gas supplied, with cross-subsidising occurring between different users, as industrial and commercial users (who have a low-cost of gas supply) pay a high price for their natural gas and a low natural gas price is applied to residential users (with a high-cost gas supply). In view of the cross-subsidising that exists between different users and the government control over residential user gas prices, it makes sense to some degree that urban gas companies then prevent upstream enterprises from developing direct supplies to users within their operational jurisdiction.

\subsubsection{Incomplete Supervisory Systems and Insufficient Supervisory Capability}

The laws that apply to natural gas are not complete, and this is not only reflected in the relatively few levels of legislation, with the majority of regulatory documents being ministerial regulations and there being no specific natural gas law, but also the fact that in certain sectors there are still no administrative regulations at all. The Mineral and Resources Law only requires submission for "authorisation or approval by the State Council", but does not actually define 
clearly what kinds of company can actually receive the "authorisation or approval" of the State Council. Although there is a fairly high hierarchical structure in Regulations for Overseas Co-operation in the Terrestrial Extraction of Oil Resources and Regulations for Overseas Co-operation in the Marine Extraction of Oil Resources, this is only applicable to foreign co-operation in extraction. The Oil and Natural Gas Pipeline Protection Law is the only administrative-type document dealing with the oil and natural gas industry at the legal level, but it was enacted to protect oil and natural gas pipelines and thereby ensure oil and natural gas transport security, and thus it mainly covers the legal issues of technical supervision. The Natural Gas Infrastructure Construction and Operation Administrative Measures provide a fairly comprehensive legal framework for supervision of the midstream natural gas industry, but lack force because they are merely ministerial regulations issued by the National Development and Reform Commission and thus lack hierarchical structure and are not particularly binding. The Oil and Gas Pipeline Network Installation Fair Access Supervisory Measures (Trial Implementation) provides the administrative framework to implement fair access to natural gas infrastructure; however, there are drawbacks in terms of the practicality of its application, with fair access actually being "negotiated access". In terms of the natural gas industry downstream sector, there are no legal documents providing an administrative framework, the legal document at the highest hierarchical level being the Urban Gas Administrative Regulations.

There is no specific natural gas industry regulator, and, apart from the areas of the environment, production safety and product quality supervisory departments, industry regulation adopts separate supervision of the upstream, midstream and downstream sectors, with co-operation and supervision divided between different departments, relying on a combined governmental supervisory approach. Under this multifaceted approach to regulation, natural gas supervisory functions are distributed between a number of departments, and inevitably there is a certain amount of duplication of roles as well as areas that are not fully covered. For example, the Ministry of Land and Resources, the National Development and Reform Commission and the National Energy Administration all have the power to decide industrial development planning and structure, to draft legislation and to establish administrative policy, while to some extent there are also jurisdictional conflicts between central government departments and local government departments.

With such a combined governmental supervisory regulatory system, there is a serious lack of supervisory input. For instance, the scheme regulation drafting team in the oil and gas section of the National Energy Administration whose area of responsibility is the "three establishments" (establishing functionality, establishing structure and establishing draft regulations) comprises less than 20 persons to cover the whole of China's oil and gas industry. Moreover, they are responsible not only for determining industrial development planning, drafting legislative framework and determining departmental procedures and industrial development strategy, but also for such supervisory functions as authorisation, surveying, co-ordination and imposition of penalties on specific individual projects, as well as the administration of work in relation to national strategic oil and gas storage. 
Open Access This chapter is licensed under the terms of the Creative Commons Attribution 4.0 International License (http://creativecommons.org/licenses/by/4.0/), which permits use, sharing, adaptation, distribution and reproduction in any medium or format, as long as you give appropriate credit to the original author(s) and the source, provide a link to the Creative Commons license and indicate if changes were made.
The images or other third party material in this chapter are included in the chapter's Creative Commons license, unless indicated otherwise in a credit line to the material. If material is not included in the chapter's Creative Commons license and your intended use is not permitted by statutory regulation or exceeds the permitted use, you will need to obtain permission directly from the copyright holder. 